Davide Galliani*

\title{
The Reducible Life Imprisonment Standard from a Worldwide and European Perspective
}

DOI 10.1515/gj-2015-0019

Abstract: Life Imprisonment, unlike the death penalty, does not attract the attention of the doctrine. There are, however, significant developments in the European Court of Human Rights case law. In this paper, using a comparative methodology, we highlight the standard that, at international level, allows to consider Life Imprisonment compatible with human dignity-that is the right to a substantial judicial review. It is no longer acceptable that the 'last word' on the lifers' early release is still entrusted to political power.

Keywords: life imprisonment, judicial review, European court of human rights, pardon power, early release power

\section{Introduction}

The purpose of this article is to demonstrate that the de jure reducibility standard of Life Imprisonment needs to be reconsidered. This is because de jure irreducible Life Imprisonment does not exist. Therefore, instead of the de jure reducible standard, it should be more appropriate to talk about de jure reducible Life Imprisonment by formal and (especially) substantial judicial review. The difference is not purely nominative. The integration of the substantial judicial review makes Life Imprisonment more respectful of human dignity. The new standard is more adequate for the relevant international law and with reference to some principles recognized around the world, as separation of power, judicial review and (of course) human dignity.

This thesis aims to demonstrate the need for making Life Imprisonment reducible through a substantial judicial review and not through a political intervention. In order to illustrate this, the working method inspired by comparative law has been used. Therefore, we will analyze how Life Imprisonment is made reducible in the world and in particular in the European context. The meaning of pardon power and Ministerial power on early release will be considered carefully.

*Corresponding author: Davide Galliani, Jean Monnet Professor of Fundamental Rights, Professor of Public Law, Department of International, Legal, Historical and Political Studies, University of Milan, Milan, Italy, E-mail: davide.galliani@unimi.it 
This article will deal with three issues. First, the constitutional provisions related to the power of pardon, with particular attention to the States of the Council of Europe that have Life Imprisonment Without Parole. Second, we will consider the ministerial power on early release. Finally, we will examine the judgments of some Constitutional Courts where the review to Life Imprisonment had to be given to the judge and not to the executive branch. Only a judge is able to evaluate, substantially and not formally, if the detention is still lawful.

In the appendix at the end of the article, there is a list of the Relevant European Law on Life Imprisonment.

The following reflections are addressed to scholars of international law, European law, constitutional law and criminal law, particularly inclined to use the comparative method; furthermore, this contribution could also affect the judges, regardless of their "jurisdiction" (international, European or national). ${ }^{1}$

\section{In which cases should de jure and therefore de facto irreducible Life Imprisonment be described?}

In order to answer this question, it is essential to focus on Constitutions which do not mention either amnesty or pardon. Only seven Constitutions in the world have no reference to either amnesty or pardon: Andorra, Australia, Bosnia and Herzegovina, Canada, Syria, Saudi Arabia and Yemen. Only two of the fortyseven Member States of the Council of Europe: Andorra and Bosnia and Herzegovina. We can add Canada, which is Observer State of the Council of Europe.

The most comprehensive International Database on amnesty and pardon worldwide ${ }^{2}$, however, reveals that amnesties, in six of these seven Countries mentioned above, have been passed anyway. Andorra is the only State in the world with no constitutional provisions on amnesty and pardon, as well as no practical experience. As a result, out of the 193 Member States of the United Nation, only one, Andorra, could be described as a State with irreducible de jure and de facto Life Imprisonment.

1 This paper is inspired by an Amicus Curiae submitted to the Grand Chamber of the European Court of Human Rights (Strasburg). The case was Hutchinson v. the United Kingdom, Application no. 57592/08. The Author of the Amicus Brief is the same of this article.

2 The Amnesty Law Database, created by Professor Louise Mallinder, University of Ulster. 


\section{Does Life Imprisonment exist in Andorra?}

No. Even though the Constitution does not prohibit Life Imprisonment explicitly (as in the case of the death penalty: article 8), no statute acknowledges it. Therefore, Life Imprisonment in Andorra is not provided by the law, and the maximum penalty is 25 years.

\subsection{First consideration}

From an international and comparative perspective, the de jure and de facto irreducible Life Imprisonment standard seems to be at least problematic. If we consider that among the 193 Member States of the United Nations, there are no States with de jure irreducible Life Imprisonment, what exactly do we mean by de jure reducible Life Imprisonment? If all States around the world allow de jure reducibility of Life Imprisonment, we have to consider only the possibility of de facto irreducible Life Imprisonment.

\section{Does Life Imprisonment exist in the six of the seven States with no constitutional references to either amnesty or pardon but with practical experiences of these?}

Yes. However, Bosnia and Herzegovina does not have Life Imprisonment- the same situation as in Andorra. Life Imprisonment in Bosnia and Herzegovina is not provided by the law (the maximum penalty is 45 years). If we consider Canada, an Observer State of the Council of Europe, the question of reducibility of Life Imprisonment is simple to solve. Canada has only Life Imprisonment With Parole. Life Imprisonment Without Parole does not exist there and, therefore, Life Imprisonment is always de jure reducible.

\subsection{Second consideration}

If we take a look at the Council of Europe, the de jure and de facto irreducible Life Imprisonment standard is definitely problematic. The only two States (Andorra, Bosnia and Herzegovina) without constitutional provisions to either 
amnesty or pardon have no Life Imprisonment. Canada has Life Imprisonment but always with Parole. Considering the Member States and the Observer States of the Council of Europe, the de jure and de facto irreducible Life Imprisonment standard cannot be empirically demonstrated. In Bosnia and Herzegovina the Constitution does not provide either pardon or amnesty. However, we do have here examples of practical experience, even though never with regard to lifers, as Life Imprisonment does not exist. As far as Canada is concerned, this is not a problem, because regardless pardon and amnesty powers, not provided in the Constitution but used de facto, Life Imprisonment is always de jure and therefore hypothetically de facto reducible.

Should such significant relevance be given to criteria with no empirical demonstration? If we cannot talk about de jure irreducible Life Imprisonment for any States in the world, why do we continue to use the criteria of the de jure reducibility?

Why did we previously focus on amnesty and especially pardon powers and not on other early release instruments? When we talk about pardon and amnesty as de jure instruments to reduce sentences, we necessarily adopt a methodology of the comparative law studies. Amnesty and pardon are the most widespread mechanisms provided by Constitutions to reduce sentences. It is quite significant that generally in the judgments involving Life Imprisonment the decisions focus first on pardon and only later, if necessary, on other particular tools, such as amnesty, early release on compassionate or medical grounds etc. ${ }^{3}$

\section{How to deal with States providing Life Imprisonment Without Parole and, especially, with reference to the pardon power?}

Only thirty-eight of the 193 Member States of the United Nations have Life Imprisonment Without Parole. ${ }^{4}$ Of these, ten are Members of the Council of

3 The most recent book in this subject is A. NovaK, Comparative Executive Clemency: The Constitutional Pardon Power and the Prerogative of Mercy in Global Perspective, Routdlege, London and New York, 2015.

4 Cruel and Unusual. U.S. Sentencing Practices in a Global Context, Center for Law ANd Global Justice, School of Law, University of San Francisco, May 2012, page 25, note 144. These States are: Albania, Argentina, Australia, Brunei Darussalam, Bulgaria, Burundi, China, Comoros, Cuba, Eritrea, Ethiopia, Ghana, Hungary, Israel, Kazakhstan, Kenya, Lao People’s Democratic Republic, Liberia, Lithuania, Malta, Marshall Islands, Namibia, Netherlands, New Zealand, 
Europe: Bulgaria, Hungary, Lithuania, Malta, the Netherlands, Slovakia, Sweden, Turkey, Ukraine, and the United Kingdom.

It is quite interesting to note that the provisions concerning Life Imprisonment Without Parole in six of these States have already been judged by the European Court of Human Rights. ${ }^{5}$ Another one is in admissibility judgment. ${ }^{6}$ Therefore, only three States have never been reviewed by the Strasbourg Court, namely Malta, Sweden, and Ukraine. ${ }^{7}$

In any case, this aspect is paramount. If it is true that, among these thirty-eight States, all of them have constitutional provisions on amnesty or pardon, it is also theoretically possible that some Constitutions expressly prohibit the use of the pardon power with reference to a particular category of convicts or limit its practice to specific convictions. In this case, and in this case only, de jure irreducible Life Imprisonment actually means de jure irreducible Life Imprisonment. All these potential cases concern States of the United States ${ }^{8}$. No Member States of the

Nigeria, Palau, Seychelles, Sierra Leone, Slovakia, Solomon Islands, Sweden, Tajikistan, Tanzania, Turkey, Ukraine, United Kingdom, and Zimbabwe. In note 145, the document underlines that there were twenty-one countries for which researchers could not locate statutory or case law text confirming whether LWOP exists or not. They are: Barbados, Bhutan, Dominica, Equatorial Guinea, Gambia, Grenada, Guyana, Indonesia, Kuwait, Lebanon, Libya, Saint Kitts and Nevis, Saint Vincent and the Grenadines, Saudi Arabia, South Sudan, Suriname, Syria, Thailand, Trinidad and Tobago, Turkmenistan, and the United Arab Emirates.

5 In chronological order: (1) United Kingdom: Vinter and Others v. UK, Grand Chamber, July 9, 2013 (Article 3 of the Convention, violation) and Hutchinson v. UK, Fourth Section, February 3, 2015 (Article 3, no violation) [referral to Grand Chamber: October 21, 2015]; (2) the Netherlands: Murray v. Netherlands, Third Section, December 10, 2013 (Article 3, no violation) [referral: January 14, 2015]; (3) Turkey: Öcalan v. Turkey (no. 2), Second Section, March 18, 2014 (Article 3, violation) [final] and Kaytan v. Turkey, Second Section, September 15, 2015 (article 3: violation) [final]; (4) Hungary: László Magyar v. Hungary, Second Section, May 20, 2014 (Article 3, violation) [final]; (5) Bulgaria: Harakchiev and Tolumov v. Bulgaria, Fourth Section, July 8, 2014 (Article 3, violation) [final]; (6) Slovakia: Cacko v. Slovakia, Third Section, July 22, 2014 (Article 3, and Article 13: no violation) [final]. For completeness, we have to mention also Trabelsi $v$. Belgium, Former Fifth Section, September 4, 2014 (Article 3, violation).

6 Lithuania: Matiošaitis v. Lithuania, Second Section, December 12, 2013, Statement of facts, app. no. 22662/13 and 7 other app.

7 We can not consider Lynch and Whelan v. Ireland, Fifth Section, July 8, 2014, app. nos. 70495/ 10 and 74565/10, a decision of inadmissibility. The reason is that in Ireland Life Imprisonment Without Parole does not appear to exist. The Irish system seems different from the one of the United Kingdom. Also the case of Cyprus is out of our considerations: after Kafkaris v. Cyprus, Grand Chamber, February 12, 2008 (Article 3, no violation; article 5, § 4, violation) the State introduced Parole (Release) Board.

8 Another interesting question here no subject to discussion, is the existence (or not) of a binding international law that prohibits the use of the clemency powers relating to genocide, crime against humanity, and others. In any case, for the Life Imprisonment in the United States, see Long-Term 
Council of Europe that provide for Life Imprisonment Without Parole have express constitutional limitation to the use of the pardon power.

\subsection{Third consideration}

All Member States of the Council of Europe provide for no constitutional limitations to the use of pardon power. All European people, regardless their sentences, could obtain pardon under the law. Once again, it is necessary to repeat the previous question: when we speak about de jure irreducible Life Imprisonment, what exactly do we mean?

\section{With reference to Council of Europe, who has the power of pardon in the States with Life Imprisonment Without Parole?}

In the Republican States, the pardon power is given to the President of the Republic (Bulgaria, Hungary, Lithuania, Malta, Slovakia, Turkey, and Ukraine). In the Monarchies, what is set forth by the law differs from what actually happens nowadays. If in the past the pardon power was a prerogative of the Monarch, now in Sweden, the Netherlands and the United Kingdom the power is substantially a matter held by the Government.

\section{Which are the possibilities for judicial review as far as pardon power is concerned?}

The power of pardon is by nature a political act. This means, first, that the power of pardon is purpose-free since the goals are not specifically set forth. For this reason, like any other political act, pardon is in principle without judicial

Imprisonment. Policy, Science, and Correctional Practice, Editor T. J. Flanagan, Sage, Thousand Oaks (Cal.), 1995, and Life Without Parole. America's New Death Penalty, Edited by C. J. OgLetreE JR. and A. Sarat, New York Universities Press, New York and London, 2012. Recently, one of the Authors that has deepened the issue of US Life Imprisonment is William W. Berry III: for example, see W. BERRY III, More Different than Life, Less Different than Death. The Argument for According Life Without Parole Its Own Category of Heightened Review Under the Eighth Amendment After Graham v. Florida, in Ohio State Law Journal, vol. 71: 6 2010, pp. 1109-1147. 
review. If the Constitution provides, for example, that 'the Head of State could grant a pardon' or 'pardon shall be granted by the Head of State', how much space could judicial review have? So, basically the power of pardon is judicial review free. Probably the most relevant demonstration of this conclusion is that granting pardon, as well as its refusal, does not need any reason or motivation. If the pardon decree of the Head of State does not contain any motivation, it is easier to understand why there is an absence of judicial review.

However, it is possible to describe some particular forms of judicial review also with reference to the pardon power. For example, if a statute sets forth that pardon can be granted only after conviction, and not before, the Head of State has to comply with this procedural requirement. Otherwise, it is possible (theoretically) to imagine judicial review of the decision. There are also examples that result from language in the statutes. Sometimes, in the statutes (not in the Constitutions) we can find some apparent restrictions to the use of pardon power. The pardon remains a purpose-free power. At most, the statutes can define some constitutional powers more specifically, but they can never change their meaning. If the statutes decide that pardon can be granted taken into account the convict's offences or the victim's opinions or the length of time serving in prison, the nature of the pardon power does not change. The problem in these cases is whether we can imagine judicial review. Maybe yes, but only in this sense- if the Head of State has used its pardon power in a completely arbitrary or grossly unreasonable way.

Even accepting this, we would still have a problem and it might be without solution. To understand if the use of the pardon power is completely arbitrary or grossly unreasonable, we would need to know how the Head of State has taken his decision. Can this be done? No, because the Head of State does not have to explain his decisions.

\subsection{Fourth consideration}

The judicial review of the pardon power is very difficult to imagine, although it cannot be totally excluded. The pardon power remains a purpose-free power without any obligation for motivations. There is definitely very little space for judge intervention.

This also in the case judicial review comes from the Constitutional Courts. The Constitutional Courts can decide which authority has the final decision on pardon. The Constitutional Courts can clarify that, for example in the parliamentary governments, the Head of State has the final decision because he or she (better than the Minister) has a 'neutral' and not a political role. In the end, the 
conclusion is always the same: the pardon power remain a purpose-free power without any obligations for motivations.

\section{Why are the possibilities of judicial review so relevant with reference to the pardon power?}

We can talk about the de jure reducible standard in the States with Life Imprisonment Without Parole only thanks to the pardon power. In these States, the pardon power is what makes Life Imprisonment de jure reducible. If the pardon power is the only possibility for a lifer without parole in these States, we should at least ask that this lifer

'shall be entitled to take proceedings by which the lawfulness of his detention shall be decided speedily by a court and his release ordered if the detention is not lawful',

as provided by Article 5, § 4 of the European Convention of Human Rights.

\section{Life Imprisonment and the Minister's role}

Even in case pardon is a governmental power, in the Minister's hands, the previous considerations do not change. The nature of this power is always the same. Pardon is still free of purpose, without any obligation for motivation.

In some States with Life Imprisonment Without Parole (as well as in others too, but we are not going to consider them), the Minister could order inmates' early release. This power usually involves all convicts, and therefore also lifers without parole. In this case too, there could be a statute or another provision (executive and administrative regulations) giving the Minister some indications. However, the power is definitely and with no doubt discretionary. We can discuss the difference between discretionary power and political power, but it would not be relevant for this issue. In both cases, the powers are concessions granted, respectively, by the Head of State and the Minister.

The Minister uses his power to satisfy the statute or other provisions, but (1) as in the case of pardon power, also in the case of early release there is no duty for specific motivations, ${ }^{9}$ and (2) only the purposes of the power of early release are binding, but not how these purposes are reached.

9 This point is crucial. In some cases, it can happen that the Minister explains the motivations of his or her decision. For example, the Minister could send a 'personal' letter to lifer. Does the 
Could the possibility of early release in the Minister's hands be described as a right? No, absolutely not. No duties, no rights. If the Minister had the obligation to grant early release for those cases provided by statutes or other regulations, the conclusion could be different. It is important to repeat: in none of the States in the world, the Minister has the obligation to grant early release. It is a concession of the Minister who uses his/her 'clemency' power to grant early release. His power is discretionary. From an inmate's point of view, we can discuss, as far as early release is concerned, about a privilege, not a right. ${ }^{10}$ The Minister may decide for early release, but he is not law obliged. As a consequence, the space for judicial review is too limited.

We could consider some judicial review space also in the case of early release by the Minister, but it is anyway very limited. The judge, for example, can take a decision regarding law violation, irrationality and procedural lack. Some examples may explain better. If the statute sets forth that early release should be granted in case life expectancy is less than three months, and the Minister ignores this rule, we can imagine a (limited) space for judicial review with reference to the unlawful grant of early release. The case of irrationality is more difficult, but we can try to explain it- a statute sets forth early release in case of inability to ambulate and the Minister does not grant it to a lifer with medically verified inability to walk (for example) more than five metres. In this case, we might see a (limited) space to judicial review. The last example is the simplest. If the Minister takes his decision with procedural lack, the judicial review could have spaces (for example, the Minister deny to grant early release without requesting the compulsory but not-binding opinion of the Parole Board or Prison Director).

In these cases, we probably can discuss the existence of formal judicial review. Regarding the substantial judicial review, the conclusion is that the spaces are very limited. If the Minister does not grant early release with specific and detailed motivations, the spaces for judicial review, also in the extreme cases of the arbitrary and capricious use of the power, appear extremely limited. It is difficult to gain real, actual, complete and substantial judicial review.

Minister have to do this? No. These particular cases are not usual and especially are not provided by law. In most cases, the Minister uses only one words: 'no'. This is what law allows. See for more (interesting) reflections, D. Griffin and I. O'DonnelL, The Life Sentence and Parole, in British Journal of Criminology, (2012) 52, pp. 611-629, and D. GRIFrin, The Release and Recall of Life Sentence Prisoners: Policy, Practice and Politics, in Irish Jurist, In Press.

10 See the excellent book of C. Appleton, Life after Life Imprisonment, Oxford University Press, Oxford, 2010. 
Is this formal and very limited judicial review enough? No. The judge can never decide if continuing detention is lawful compared to the original sentence. However, only the judge has the duty to disclose the reasoning and the documents used for the decision. The procedure will be made transparent only with the judge, as only the judge is formally independent and impartial from the parties. Finally, only the judge is substantially bound to respect the jurisdictional procedures and guarantees- one of the most important of them is the adversarial way to reach the final decision.

\subsection{Fifth consideration}

In case the possibility to allow an early release is a Minister's power, due to the nature of this power, it is very difficult to show a concrete, actual and especially substantial possibility of judicial review. Early release power is by nature discretionary, with no duty for motivations. Therefore, a convict does not have a right but a privilege. This is the reason why in front of a privilege (and not a right) the judicial review should be described as very limited.

\section{Life Imprisonment, the purposes of the penalties and the Minister's role}

The last, but not least important, observation is that we can examine the States in which Life Imprisonment (often mandatory) has only one purpose- punishing the convict. Without considering the merit of this choice, this is what happens in some States. ${ }^{11}$ It can also occur that lifers, in some of these States, are not allowed to ask for early release to a judge or (at least) a parole board. The only possibility is early release by the Minister.

This (apparently) entangled system, however, shows an evident contradiction, with relevant consequences even to the basis of the Rule of Law. On one hand, the sole punitive purpose of Life Imprisonment makes early release a privilege (not a right), but, on the other hand, the judicial review on early release should guarantee something that is not possible to guarantee. The contradiction is clear and undeniable- if early release is a privilege, and not a

11 Apart from the importance of rehabilitation, highlighted by the Resolutions of the Council of Europe (see Appendix), in some of these States, where Life Imprisonment has only retributive scope, the deterrent goal of penalties is deny because it is against human dignity! 
right, the space for a substantial judicial review is fictional, unreal, and nonexistent. $^{12}$

The Rule of Law, realised by a real separation of powers, an actual judicial review, and a material guarantee of the human dignity, is a conquest that does not deserve formal deference. The Rule of Law deserves substantial, valid and reasonable observance. ${ }^{13}$

\section{Relevant Constitutional Court's judgements}

In Italy, the Constitutional Court, in sentence no. 204 of July 4, 1974, declared the constitutional illegitimacy of the Minister's power to grant conditional release ('liberazione condizionale') that has been allowed also for Lifers (only) since 1962, using these words (our translation, italic added):

'§2. Conditional release represents a particular aspect of the executive moment of the penalty and it is part of the ultimate and decisive goal of the penalty itself that is to tend to the social rehabilitation of the convicted (...), ${ }^{14}$

'Thanks' to article $27, \S 3$ of the Constitution, ${ }^{15}$ conditional release has acquired a more incisive weight and value than in the past. It represents, by nature, a peculiar aspect of the penal treatment and its application took a peremptory duty to legislator to consider not only the rehabilitation goal of the penalty, but also to arrange all adequate instruments to achieve this goal and the forms trough which this goal can be guarantee' ${ }^{16}$

12 Without considering that, in the case of mandatory Life Imprisonment, the problem doubles. The space of the judicial review is limited at the beginning and at the end.

13 This is the common thread of the most important book on Life Imprisonment ever published: D. VAn ZyL Smit, Taking Life Imprisonment Seriously in National and International Law, Kluwer Law International, The Hague, 2002. See also (at least), La perpétuité perpétuelle. Réflexion sur la réclusion criminelle à perpétuité, Sous la direction de Y. LÉcuYER, Préface de K. Vasak, Presses Universitaires de Rennes, Rennes, 2012.

14 '§2. L'istituto della liberazione condizionale rappresenta un particolare aspetto della fase esecutiva della pena restrittiva della libertà personale e s'inserisce nel fine ultimo e risolutivo della pena stessa, quello, cioè, di tendere al recupero sociale del condannato (...)'.

15 Article 27, § 3 of the Italian Constitution: 'Punishment cannot be inhuman treatment and must aim at the rehabilitation of the convict' ('Le pene non possono consistere in trattamenti contrari al senso di umanità e devono tendere alla rieducazione del condannato').

16 'Con l'art. 27, terzo comma, della Costituzione l'istituto ha assunto un peso e un valore più incisivo di quello che non avesse in origine; rappresenta, in sostanza, un peculiare aspetto del trattamento penale e il suo ambito di applicazione presuppone un obbligo tassativo per il 
'As a result, by virtue of constitutional article (no. 27, §3), arise the right of the convicted in order that, occurring the conditions provided by law (the 'secure rehabilitation', 'sicuro ravvedimento', ndr), the continuing punitive pretence be reviewed to verify if the quantity of the expiate penalty has positively carry out its rehabilitation goal. This right shall obtain a valid and reasonable jurisdictional guarantee, ${ }^{17}$

'There is no doubt that the law in force is completely deficient of this guarantee. The law determines an abnormal sequence of interventions and responsibilities, which move from the judge of the executive moment ('giudice di sorveglianza', ndr) to the Minister of Justice.

In such a significant phase of the executive moment of the penalty, this connection between an authority of the judiciary and an authority of the executive power contrasts with the guarantee of the personal liberty which the article 24 of the Constitution, ${ }^{18}$ within Article $13,{ }^{19}$ ensures the judicial safeguard for.

It should be noted that the Minister of Justice has such a wide discretionary power that he or she can disregard the opinion of the judicial authority as far the request for the application of the conditional release. The judicial authority, thanks' to its functions on the executive moment of the penalty provided by law, is the only adequate authority who can evaluate the real and concrete existence of the objective and subjective conditions (especially the second one) that are essential to grant conditional release'. ${ }^{20}$

legislatore di tenere non solo presenti le finalità rieducative della pena, ma anche di predisporre tutti i mezzi idonei a realizzarle e le forme atte a garantirle'.

17 'Sulla base del precetto costituzionale sorge, di conseguenza, il diritto per il condannato a che, verificandosi le condizioni poste dalla norma di diritto sostanziale, il protrarsi della realizzazione della pretesa punitiva venga riesaminato al fine di accertare se in effetti la quantità di pena espiata abbia o meno assolto positivamente al suo fine rieducativo; tale diritto deve trovare nella legge una valida e ragionevole garanzia giurisdizionale'.

18 Article 24, § 1: 'All persons are entitled to take judicial action to protect their individual rights and legitimate interests'.

19 Article 13, $\S 1$ of the Italian Constitution: 'Personal liberty is inviolable. No form of detention, inspection or personal search nor any other restriction on personal freedom is admitted, except by a reasoned warrant issued by a judicial authority, and only in the cases and the manner provided for by law'.

20 'Non v'é dubbio che tale garanzia é del tutto carente nel procedimento previsto dal vigente ordinamento giuridico. Per la normativa in atto si determina, infatti, un'anomala successione di interventi e di attribuzioni che vanno dal giudice di sorveglianza al Ministro della giustizia. Un siffatto legame tra organo del potere giudiziario e organo del potere esecutivo, in un aspetto così importante della fase esecutiva della pena, contrasta con quelle guarentigie che attengono alla libertà personale, in riferimento alla quale l'art. 24 della Costituzione, nel quadro dei precetti contenuti nell'art. 13, ne assicura la tutela giurisdizionale. Devesi rilevare che il Ministro della giustizia gode di una discrezionalità talmente ampia da poter disattendere il 
'The disharmony of the system is even more unacceptable after law no. 1643, November 25, 1962, that has modified the original text of Article 167 of the Penal Code extending the application of the conditional release to the Life Imprisonment convicted.

Due to law no. 1634 of the 1962, conditional release had taken, with no doubt, a different appearance and dimension compared to what provided for by the legislator in 1930. Albeit subject to predetermined conditions, we are facing an actual surrender by the State to further realization of the punitive pretence with reference to certain convicts, surrender that surely cannot depend on an authority of the executive power, but on the judicial power, with all guarantees both for the State and for the convicted'. ${ }^{21}$

The Italian Constitutional Court did not care about the subsequently legal vacuum. A hypothetical renunciation by the State to the further realization of the punitive pretence cannot depend on an authority of the executive power. After the historical sentence no. 204 of 1974, all Italian Constitutional Court judgments on Life Imprisonment have declared it constitutionality lawful to the possibility to obtain conditional release under real and concrete judicial review.

Considering the first decision of the Italian Constitutional Court directly concerning Life Imprisonment, sentence no. 264 of November 22, 1974, decided five months after the sentence no. 204, the words used are unequivocal:

'Sentence no. 204 of 1974 is a remarkable judgment by which the Constitutional Court declared unconstitutional the law which attributed to the Minister of Justice the power to grant conditional release. This will therefore be granted no more in relation to discretionary decisions of political power, but on the basis of a court decision, which the person is entitled to apply to, and with the guarantees proper of

parere espresso, sulla istanza per l'applicazione del beneficio, dall'organo giudiziario, il solo idoneo, per le funzioni attribuitegli dalla legge nel processo esecutivo della pena, a poter valutare l'effettiva esistenza in concreto delle condizioni oggettive e soggettive - particolarmente quest'ultime - per la concessione di esso beneficio.'

21 'La disarmonia del sistema appare ancor più inaccettabile a seguito della legge 25 novembre 1962, n. 1634, che ha modificato il testo originario dell'art. 176 del codice penale e che, tra l'altro, ha esteso l'applicazione dell'istituto della liberazione condizionale anche ai condannati all'ergastolo. Per la legge n. 1634 del 1962 la liberazione condizionale assume senz'altro una fisionomia e una dimensione diverse da quelle attribuitele dal legislatore del 1930. Siamo in presenza di una vera e propria rinuncia, sia pure sottoposta a condizioni prestabilite, da parte dello Stato alla ulteriore realizzazione della pretesa punitiva nei riguardi di determinati condannati, rinuncia che non può certamente far capo ad un organo dell'esecutivo, ma ad un organo giudiziario, con tutte le garanzie sia per lo Stato che per il condannato stesso'. 
the judicial proceedings ensuring the offender has taken such a behaviour so as to feel his rehabilitation secure'.22

\subsection{Sixth consideration}

Substantial judicial review, in case of Life Imprisonment Without Parole, is fundamental not only for the convicted but also for the State. The judicial review allows to protect society, not only inmates.

\section{Conclusion}

It is noteworthy that in sentence no. 204 of 1974 of the Italian Constitutional Court, the judges did not take into account the issue of the pardon power, provided by the Constitution. They could have referred to it, but they did not. ${ }^{23}$ Another Constitutional Court, whose importance is recognized worldwide, had used clear words:

'Implementing a prison sentence in accordance with human dignity requires that the person sentenced to life imprisonment retains the opportunity to regain his freedom. The possibility of pardon alone is not sufficient, ${ }^{24}$

What will the destiny of the Minister's power be? We can conclude with an unequivocal statement:

'However, with the wider recognition of the need to develop and apply, in relation to mandatory life prisoners, judicial procedures reflecting standards of

22 Di particolare rilievo è per altro la sentenza n. 204 del 1974 della Corte costituzionale che ha dichiarato l'illegittimità della norma che attribuiva al Ministro della giustizia la facoltà di concedere la liberazione condizionale. Questa pertanto sarà concessa non più in relazione a scelte discrezionali del potere politico, ma in base ad una decisione dell'autorità giudiziaria (cui l'interessato avrà diritto di rivolgersi) che con le garanzie proprie del procedimento giurisdizionale accerterà se il condannato abbia tenuto un comportamento tale da far ritenere sicuro il suo ravvedimento'.

23 Instead, the Italian Constitutional Court has continued in the direction indicated in the sentence no. 204 of 1974. For example, the sentence no. 192 of 1976 has declared the illegitimacy of the power of the Minister to grant conditional release to convicts by the provisions contained in the Military Penal Code.

24 „Zu den Voraussetzungen eines menschenwürdigen Strafvollzugs gehört, daß dem zu lebenslanger Freiheitsstrafe Verurteilten grundsätzlich eine Chance verbleibt, je wieder der Freiheit teilhaftig zu werden. Die Möglichkeit der Begnadigung allein ist nicht ausreichend“ (45 BVerfGE 187, June 21, 1977). Thanks' to Professor Dirk Van Zyl Smit for the translation. 
independence, fairness and openness, the continuing role of the Secretary of State in fixing the tariff and in deciding on a prisoner's release following its expiry has become increasingly difficult to reconcile with the notion of separation of powers between the executive and the judiciary, a notion which has assumed growing importance in the case-law of the Court'. ${ }^{25}$

From a more general point of view, it is paramount that States allow judges to use their powers. If the decision on lifers' early release continues to be a political issue, some of the most important principles of the Constitutional States may be only theoretical and not practical. These principles are the separation of powers and the respect for human dignity.

If politicians have the 'last word' on lifers, they might use the detainee as a means to obtain votes during an election campaign (or not to lose them during their term). This would mean a violation of the human dignity, a right any person, whether in prison or not, must have.

Acknowledgments: The Author would like to thank all the people who read this article and who provided valuable suggestions: Dirk Van Zyl Smit (University of Nottingham, UK), Connie de la Vega (University of San Francisco, US), Cesare Romano (Loyola Law School, Los Angeles, US), Michael M. O’ Hear (Marquette University Law School, Milwaukee, US), and William W. Berry III (University of Mississippi, US).

Funding: This paper was discussed with the member of the research project 'The Right to Hope. Life Imprisonment in the European Context', co-funded by the European Union of which the Author is the Scientific Coordinator (project no. 553149-epp-1-2014-iteppjmo-module).

\section{Appendix: Relevant European Law on Life Imprisonment (Without Parole) (bold added)}

\section{(a) Res (73) 5, Standard Minimum Rules for the Treatment of Prisoners, January 19, 1973}

Rule 5, $\S 3$ - Deprivation of liberty shall be effected in material and moral conditions which ensure respect for human dignity.

25 European Court of Human Rights, Stafford v. UK, Grand Chamber, May 28, 2002, § 78 (unanimously finding violation of Article 5, § 1 and Article 5, § 4). 
Rule 59 - The purpose and justification of a sentence of imprisonment or a similar measure depriving a person of liberty is ultimately to protect society against crime. This end can only be achieved if the period of imprisonment is used to ensure, so far as possible, that upon his return to society the offender is not only willing but able to lead a law-abiding and self-supporting life.

Rule 66 - The treatment of persons sentenced to imprisonment or a similar measure shall have as its purpose, so far as the length of the sentence permits, to establish in them the will to lead law-abiding and self-supporting lives after their release and to fit them to do so. The treatment shall be such as will encourage their self-respect and develop their sense of responsibility.

\section{(b) Res 76 (2), on the treatment of long-term prisoners, February 17, 1976}

$\S$ 9. Ensure that the case of all prisoners will be examined as early as possible to determine whether or not a conditional release can be granted.

$\S 10$. Grant the prisoner conditional release, subject to the statutory requirements to time served, as soon as a favorable prognosis can be formulated; consideration of general prevention alone should non justify refusal of conditional release.

$\S 12$. Ensure that a review, as referred to in 9, of the life sentence should take place, if not done before, after eight to fourteen years of detention and be repeated at regular intervals.

$\S 15$. Take all steps to ensure a better understanding by the general public of the special problems of long-term prisoners, thereby creating a social climate favorable to their rehabilitation.

\section{(c) $\operatorname{Rec}(99) 22$, concerning prison overcrowding and prison population inflation, September 30, 1999}

$\S 23$. The development of measures should be promoted which reduce the actual length of the sentence served, by living preference to individualised measures, such as early conditional release (parole), over collective measures for the management of prison overcrowding (amnesties, collective pardons).

$\S 24$ Parole should be regarded as one of the most effective and constructive measures, which not only reduces the length of imprisonment but also contributes substantially to a planned return of the offender to the community. 


\section{(d) $\operatorname{Rec}(2003)$ 22, on conditional release, September 24, 2003}

$\S 1$. For the purposes of this recommendation, conditional release means the early release of sentenced prisoners under individualised post-release conditions. Amnesties and pardons are not included in this definition.

$\S 4 . a$. In order to reduce the harmful effects of imprisonment and to promote the resettlement of prisoners under conditions that seek to guarantee safety of the outside community, the law should make conditional release available to all sentenced prisoners, including life-sentence prisoners. ${ }^{26}$

$\S 5$. When starting to serve their sentence, prisoners should know either when they become eligible for release by virtue of having served a minimum period (defined in absolute terms and/or by reference to a proportion of the sentence) and the criteria that will be applied to determine whether they will be granted release ("discretionary release system") or when they become entitled to release as of right by virtue of having served a fixed period defined in absolute terms and/or by reference to a proportion of the sentence ("mandatory release system").

$\S$ 6. The minimum or fixed period should not be so long that the purpose of conditional release cannot be achieved.

$\S 18$. The criteria that prisoners have to fulfil in order to be conditionally released should be clear and explicit. They should also be realistic in the sense that they should take into account the prisoners' personalities and social and economic circumstances as well as the availability of resettlement programmes. ${ }^{27}$

26 Explanatory Memorandum, Paragraph 4: 'Life-sentence prisoners should not be deprived of the hope to be granted release either. Firstly, no one can reasonably argue that all lifers will always remain dangerous to society. Secondly, the detention of persons who have no hope of release poses severe management problems in terms of creating incentive to co-operate and address disruptive behaviour, the delivery of personal-development programmes, the organisation of sentence-plans and security. Countries whose legislation provides for real-life sentences should therefore create possibilities for reviewing this sentence after a number of years and at regular intervals, to establish whether a life-sentence prisoner can serve the remainder of the sentence in the community and under what conditions and supervision measures'.

27 Explanatory Memorandum, Paragraph 18: 'The criteria should be clear and explicit so as to avoid erratic decisions or disparities in decision-making. This requirement is also in the interest of the prisoners and the staff involved in the preparation of release. The lack of clear and explicit criteria might lead to reduced confidence in the system and less motivation on the part of prisoners to participate actively in the preparation for conditional release. A similar lack of confidence or motivation would be produced if the criteria were felt to be unrealistic, in other words, impossible to fulfil given the prisoner's personal and social circumstances (such as age, family situation, health, professional qualifications etc) and the unavailability of resettlement programmes. If a prison service does not create conditions for the maintenance of family ties, for work during detention and for participation in training and especially in treatment programmes to 
$\S 19$. The lack of possibilities for work on release should not constitute a ground for refusing or postponing conditional release. Efforts should be made to find other forms of occupation. The absence of regular accommodation should not constitute a ground for refusing or postponing conditional release and in such cases temporary accommodation should be arranged.

$\S 20$. The criteria for granting conditional release should be applied so as to grant conditional release to all prisoners who are considered as meeting the minimum level of safeguards for becoming law-abiding citizens. It should be incumbent on the authorities to show that a prisoner has not fulfilled the criteria.

$\S 32$. Decisions on granting, postponing or revoking conditional release, as well as on imposing or modifying conditions and measures attached to it, should be taken by authorities established by law in accordance with procedures covered by the following safeguards:

(a) convicted persons should have the right to be heard in person and to be assisted according to the law;

(b) the decision-making authority should give careful consideration to any elements, including statements, presented by convicted persons in support of their case;

(c) convicted persons should have adequate access to their file;

(d) decisions should state the underlying reasons and be notified in writing.

\section{(e) $\operatorname{Rec}(2003)$ 23, Management of Life Sentence (October 9, 2013)}

Considering that the abolition of the death penalty in member states has resulted in an increase in the use of life sentences;

address aggressive or offending behaviour and drug or alcohol problems, a prisoner cannot be expected to overcome his/her shortcomings in these fields during detention. To be realistic, the criteria related to these issues should, therefore, not be too rigid but should take account of the possibilities to address existing shortcomings during detention or after release in the community. The lack of such possibilities in prison or in the community should not preclude conditional release. Care should also be taken to avoid criteria that are too closely related to the type of the offence committed, or the dangerousness of the offender at the start of his/her prison sentence. It has to be recalled that such criteria have already been used to decide on the length of the sentence and the classification and sentence plan of the prisoner. The decision to grant conditional release should be based on realistic criteria related to the present situation and prospects of the prisoner'. 
Concerned about the increase, in many countries, in the number and length of long-term sentences, which contribute to prison overcrowding and may impair the effective and humane management of prisoners;

(...)

$\S 2$. The aims of the management of life sentence and other long-term prisoners should be: (...)

- to increase and improve the possibilities for these prisoners to be successfully resettled in society and to lead a law-abiding life following their release.

$\S 3$. Consideration should be given to the diversity of personal characteristics to be found among life sentence and long-term prisoners and account taken of them to make individual plans for the implementation of the sentence (individualisation principle).

$\S 10$. Sentence plans should include a risk and needs assessment of each prisoner and be used to provide a systematic approach to: (...)

- participation in work, education, training and other activities that provide for a purposeful use of time spent in prison and increase the chances of a successful resettlement after release;

- interventions and participation in programmes designed to address risks and needs so as to reduce disruptive behaviour in prison and re-offending after release;

- conditions and supervision measures conducive to a law-abiding life and adjustment in the community after conditional release.

$\S 16$. Since neither dangerousness nor criminogenic needs are intrinsically stable characteristics, risk and needs assessments should be repeated at intervals by appropriately trained staff to meet the requirements of sentence planning or when otherwise necessary.

$\S 31$. Special management care and attention should be given to the particular problems posed by prisoners who are likely to spend their natural life in prison. In particular, their sentence planning should be sufficiently dynamic and allow them to benefit from participation in meaningful activities and adequate programmes including interventions and psychosocial services designed to help them cope with their sentence.

$\S 35$. If, following revocation of conditional release, a life sentence or longterm prisoner is returned to prison, the principles enumerated in the foregoing should continue to be followed. In particular, a further assessment of risk and criminogenic needs should be undertaken and used for choosing a suitable allocation and further interventions, with the aim of preparing the prisoner for early reconsideration for release and resettlement in the community. 